\title{
Ross Sea deep-ocean and epipelagic microzooplankton during the summer-autumn transition period
}

\author{
Karl A. Safi ${ }^{1, *}$, Karen V. Robinson ${ }^{2}$, Julie A. Hall ${ }^{3}$, Jill Schwarz ${ }^{3}$, Elizabeth W. Maas ${ }^{3}$ \\ National Institute of Water and Atmospheric Research, ${ }^{1}$ PO Box 11-115, Hamilton, ${ }^{2}$ PO Box 8602, Christchurch, \\ and ${ }^{3}$ Private Bag 14901, Wellington, New Zealand
}

\begin{abstract}
Microzooplankton populations are key participants in the transfer, recycling and export of carbon in epipelagic waters, but little is known about their role, abundance and diversity at depth, especially in the Antarctic region. We surveyed microzooplankton populations and their potential prey in the Ross Sea area from $66^{\circ} \mathrm{S}$ to $77^{\circ} \mathrm{S}$ during the New Zealand IPY-CAML survey, 12 February to 11 March 2008. Samples were taken throughout the available water column at depths between $\sim 5$ and $3400 \mathrm{~m}$, allowing us to compare deeper, largely unknown, mesopelagic and bathypelagic waters with the traditionally studied epipelagic zone. Microzooplankton diversity and abundance were highest in the high chlorophyll $a$, diatom-dominated waters of the epipelagic zone, but occasionally, peaks did occur in the upper mesopelagic before populations declined with depth. Ciliates and dinoflagellates declined more rapidly than heterotrophic nanoflagellates, which led to the latter dominating at depth. Ciliate populations in epipelagic waters were correlated with bacteria, picophytoplankton and chlorophyll $a$, but these potential prey did not correlate well with heterotrophic nanoflagellates in deeper or low-biomass waters. Despite their rapid decline with depth, due to the large volume of deeper waters, the total integrated microzooplankton biomass exceeded that found in the epipelagic zone. This indicates that the deeper waters of the Ross Sea, at this time, contained a significant pool of microzooplankton biomass. These deeper populations are likely to aid in the recycling and remineralisation of sinking phytoplankton biomass traditionally thought to be exported to the ocean floor.
\end{abstract}

KEY WORDS: Microzooplankton $\cdot$ Protists $\cdot$ Mesopelagic $\cdot$ Bathypelagic $\cdot$ Epipelagic $\cdot$ Ross Sea Resale or republication not permitted without written consent of the publisher

\section{INTRODUCTION}

A diverse assemblage of microzooplankton is known to inhabit the Ross Sea region and is dominated by heterotrophic protistan species, including substantial populations of ciliated protozoa, heterotrophic dinoflagellates and choanoflagellates (Garrison \& Gowing 1993, Marchant \& Murphy 1994, Garrison et al. 1996, Scott \& Marchant 2005). In Southern Ocean waters, microbial food web processes centred around microzooplankton often dominate biological processes in the epipelagic zone, especially during post-bloom successional periods when phytoplankton biomass is low (Alder \& Boltovskoy 1993, Garrison et al. 1996, Dennett et al. 2001). In the deeper waters of this region, however, beyond the epipelagic zone, little is known about the biomass or role of microzooplankton.

Microzooplankton through grazing are responsible for much of the transfer of smaller phytoplankton and bacteria through the food web (Burkill et al. 1995, Becquevort 1997, Klaas 1997, Fonda Umani et al. 
1998, Caron et al. 2000, Hall \& Safi 2001, Landry et al. 2002). In both surface water and increasingly at depth, microzooplankton influence carbon transfer and export through their influence on food web processes (Caron et al. 2000, Tanaka 2009, Sohrin et al. 2010). In epipelagic waters, this may be achieved by uppressing phytoplankton population growth through grazing (Burkill et al. 1995, Timmermans et al. 2001) and by repackaging smaller phytoplankton biomass (Rivkin et al. 1999) for larger predators, both processes providing a path for the flux of carbon. Microzooplankton may even enhance carbon flux into deeper Southern Ocean waters by favouring the growth of larger, faster-sinking species (Hall \& Safi 2001, Landry et al. 2002). Due to their substantial potential for carbon consumption, growth and turnover, microzooplankton are also important in nutrient cycling in both the epipelagic zone and deeper waters (Brzezinski et al. 2001, Fennel \& Neumann 2003). More recent studies in some marine systems now suggest that the majority of particulate organic carbon thought to be exported may be remineralised with the aid of protist grazing and bacterial activity and hence may never reach the deep ocean (Buesseler \& Boyd 2009, Tanaka 2009, Sohrin et al. 2010). This in turn has important implications, especially if similar processes occur in Southern Ocean waters, which are regarded as an important sink for atmospheric carbon.

Microzooplankton also serve as an important food source for larger predators, such as mesozooplankton, in the Ross Sea region (Caron et al. 1999, 2000, Lonsdale et al. 2000). Conversely, the impact of mesozooplankton grazing on microzooplankton biomass appears to be only modest due to the relatively low biomass of these larger predators reported in these waters (Lonsdale et al. 2000). Until now, little has been known about the abundance and potential role of these organisms in the deeper waters of the Ross Sea region.

The present study was undertaken following the spring-summer period when phytoplankton biomass peaks occur (Arrigo et al. 1998, Smith et al. 2000a,b, Dennett et al. 2001) but before the onset of the heterotrophic, low phytoplankton biomass period characteristic of autumn in the Ross Sea (Dennett et al. 2001). To date, studies in the Ross Sea region have not captured this transitional period and have been largely limited to the epipelagic zone (Vanucci \& Bruni
1999, Caron et al. 2000, Dennett et al. 2001). The aim of the present study was to find out how microzooplankton populations in the Ross Sea vary during this transition period, both spatially and with depth. We also aimed to determine whether the amount of microzooplankton biomass at depth was sufficient to influence carbon export to the ocean floor through recycling processes. Finally, we investigated the relationship between microzooplankton and their potential prey and how this changes with depth.

\section{MATERIALS AND METHODS}

\section{Field sampling}

Samples were collected during the New Zealand International Polar Year (IPY) Census of Antarctic Marine Life (CAML) voyage to the Ross Sea on board the RV 'Tangaroa' (voyage 0802) between 12 February and 11 March 2008. At 19 sites, a Seabird (SBE-9 plus) conductivity, temperature and depth sensor (CTD) and rosette fitted with 24 Niskin bottles $\left(\begin{array}{ll}10 & 1\end{array}\right)$ was used to collect sample water and assess a variety of physical and biological variables (Table 1, Fig. 1).

\section{Epipelagic, mesopelagic, bathypelagic and mixed layer depth}

As light measurements were not taken during CTD casts, epipelagic (euphotic) zone depths were calculated using the method of Morel \& Genitili (2004) (see also Morel et al. 2007) using ocean colour data from the Aqua-MODIS sensor (Table 2). Epipelagic depths were generated using $9 \mathrm{~km}$ spatial resolution data composited across the
Table 1. Sampling region, area, bottom depth and site number of sites surveyed during the NZ IPY-CAML voyage to the Ross Sea region, 12 February to 11 March 2008

\begin{tabular}{|lccc|}
\hline Region & Area & Depth $(\mathrm{m})$ & Site numbers \\
\hline South & Shelf & $200-400$ & C1, \\
South & Shelf & $400-600$ & C3, C4 \\
South & Shelf & $600-1200$ & C2 \\
Central & Slope (west) & $600-1200$ & C16, C26 \\
Central & Slope (west) & $1200-2000$ & C17, C27 \\
Central & Slope (shallow) & $400-600$ & C15, C25 \\
Central & Deep slope & $2000-2500$ & C18 \\
North & Abyss & $2800-3500$ & C30, C33, C35 \\
North & Seamounts & $400-3000$ & C24, C29, C31, C34 \\
\hline
\end{tabular}




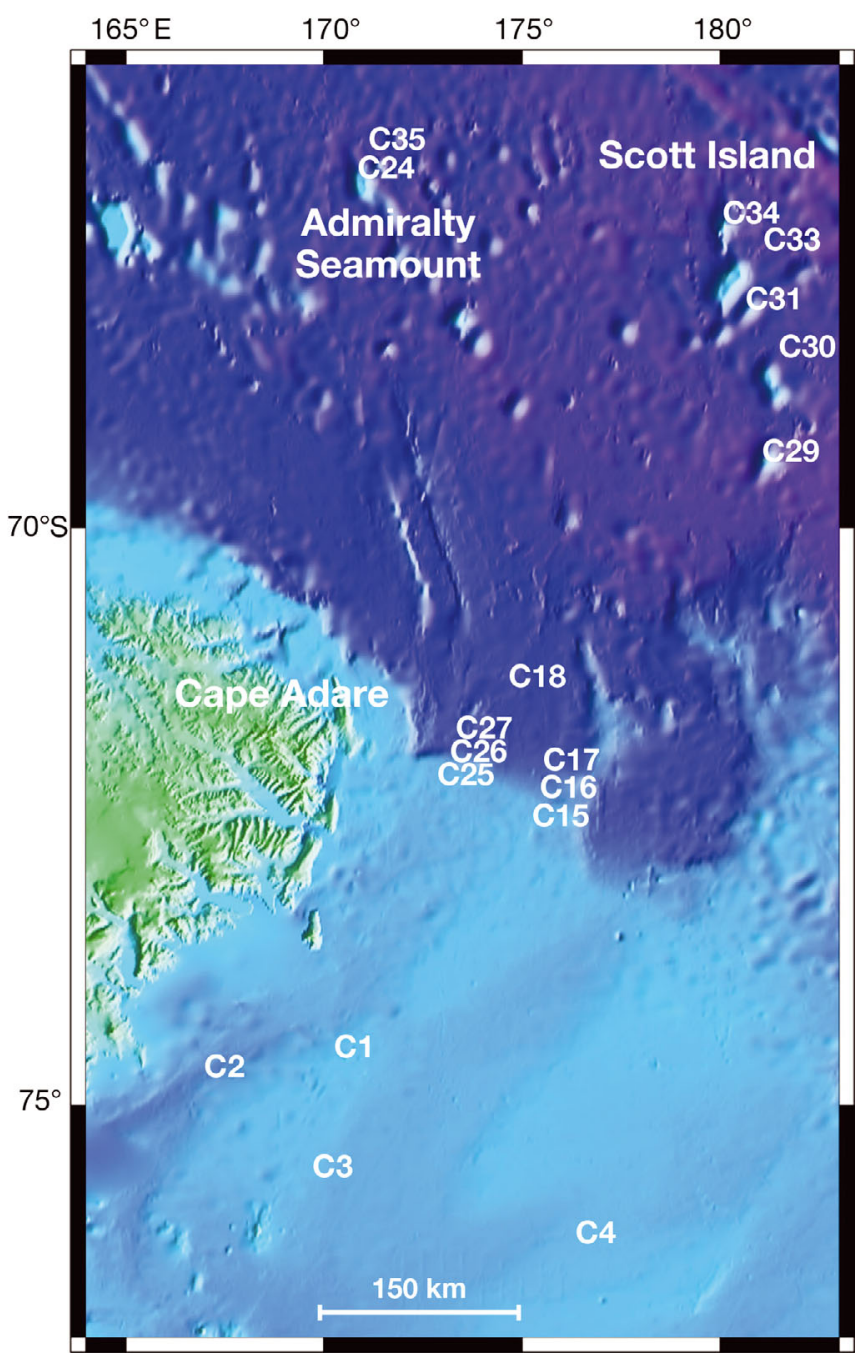

Fig. 1. Sampling sites surveyed during the NZ IPY-CAML voyage to the Ross Sea region, 12 February to 11 March 2008

voyage time period with the NASA freeware 'SeaDAS'. Having identified epipelagic zone depths, we defined the mesopelagic zone as depths occurring between our calculated epipelagic zone depth and $1000 \mathrm{~m}$. Depths >1000 m were considered to be bathypelagic. Mixed layer depths (MLD) were also calculated from CTD data collected during the voyage (Table 2) where data were available. When CTD data were not available, temperature and salinity profiles from Seabird Microcat devices deployed with other instruments were used to calculate the MLD. Where data were available from $>1$ source, an average was taken and used as the calculated MLD for these sites. Water masses were also categorised following Sokolov \& Rintoul (2002, 2007).
Table 2. Epipelagic and mixed layer depths (m) at sites surveyed during the NZ IPY-CAML voyage to the Ross Sea region, 12 February to 11 March 2008

\begin{tabular}{|lcc|}
\hline Site number & $\begin{array}{c}\text { Epipelagic zone } \\
\text { depth }\end{array}$ & $\begin{array}{c}\text { Mixed layer } \\
\text { depth }\end{array}$ \\
\hline C1 & 47 & 36 \\
C2 & 36 & 30 \\
C3 & 33 & 55 \\
C4 & 36 & 55 \\
C15 & 92 & 43 \\
C16 & 83 & 43 \\
C17 & 92 & 47 \\
C18 & 86 & 72 \\
C24 & 98 & 51 \\
C25 & 97 & 28 \\
C26 & 97 & 39 \\
C27 & 48 \\
C29 & 72 & 26 \\
C30 & 68 & 39 \\
C31 & 69 & 45 \\
C33 & 74 & 48 \\
C34 & 80 & 19 \\
C35 & 80 & 35 \\
\hline
\end{tabular}

\section{CTD sampling}

Water samples were collected at 9 to 15 discrete depths at each core site using 101 Niskin bottles mounted on the CTD rosette (Fig. 1, Table 1). Dissolved nutrients (nitrate + nitrite, phosphate and silicate) were measured using an AlpKem nutrient analyser (Cowley et al. 1999). Chlorophyll a (chl a) was determined fluorometrically by filtering 500 to $1000 \mathrm{ml}$ of seawater onto $25 \mathrm{~mm}$ Whatman glass fibre filters $(\mathrm{GF} / \mathrm{F})$. Filters were immediately frozen and analysed within 3 mo following the methods of Strickland \& Parsons (1972) and using a PerkinElmer fluorometer. Discrete water samples were also collected for determination of ciliated protozoa, nauplii, nanoflagellates, bacteria, picophytoplankton and phytoplankton abundance and biomass.

\section{Microzooplankton identification and enumeration}

Ciliates and small mesozooplankton (miscellaneous non-ciliates) were identified and enumerated in samples using the sedimentation method with $250 \mathrm{ml}$ to 21 samples preserved with Lugol's iodine solution (1\% final concentration). For enumeration, samples were left to settle for $>48 \mathrm{~h}$ then counted and identified with an inverted microscope at $100 \times$ to 400× magnification. Ciliates and small mesozooplankton samples were identified to genus and/or 
species level (Brandt 1906, Kofoid \& Campbell 1929, 1939, Corliss 1961, Alder 1999, Scott \& Marchant 2005). The dimensions of each taxon were measured, and the volume was estimated from approximated geometric shapes (spheres, cones or ellipsoids). Estimates of ciliate volume were then converted to car-

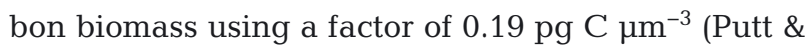
Stoecker 1989) and combined with abundances to give total biomass. Tintinnid ciliate volume was halved to compensate for lorica volume (Beers \& Stewart 1967). Miscellaneous non-ciliates were estimated to be $0.2 \mu \mathrm{g} \mathrm{C}$ per individual, based on mean literature values of the most commonly observed species (N. Broekhuizen pers. comm.).

Subsamples for nanoflagellate counts were preserved in glutaraldehyde, filtered and stained with primulin following the methods described by Hall et al. (2004). Nanoflagellates were counted under UV excitation using a Leica compound microscope with autotrophic nanoflagellates (ANF) differentiated by chl a excitation (Hall et al. 2004). Where possible, given their preservation, all abundant organisms were identified to genus and/or species level (Chretiennot-Dinet et al. 1990, Patterson \& Larson 1991, Throndsen 1993, Tomas 1997, Scott \& Marchant 2005, Hoppenrath et al. 2009) or classed by size $(<2 \mu \mathrm{m}, 2$ to $5 \mu \mathrm{m}$ and 5 to $20 \mu \mathrm{m})$ and then counted. Cell carbon for ANF and heterotrophic nanoflagellates (HNF) was calculated from cell volumes using formulae representing geometric solids that approximated their shape (Rott 1981) and a conversion factor of $0.13 \mathrm{pg} \mathrm{C} \mathrm{m}^{-3}$ (Edler 1979).

\section{Dinoflagellates}

Smaller dinoflagellates $<20 \mu \mathrm{m}$ were identified and included in nanoflagellate counts for all depths. Larger $(>20 \mu \mathrm{m})$ dinoflagellates were identified in Lugol-preserved samples to a depth of $100 \mathrm{~m}$ following the methods reported by Chang et al. (in press).

\section{Picophytoplankton and bacteria}

Picophytoplankton and bacterial samples were frozen in liquid nitrogen (Lebaron et al. 1998) and thawed immediately before counting by flow cytometry. For picophytoplankton analysis, we followed the methods of Hall et al. (1999), and for bacteria, we followed Safi et al. (2007). Cell carbon for eukaryotic picophytoplankton was determined by estimating the average spherical diameter and converted fol- lowing Booth (1988) to yield a factor of $920 \mathrm{fg} \mathrm{C} \mathrm{cell}^{-1}$. For Bacteria, a conversion factor of $20 \mathrm{fg} \mathrm{C} \mathrm{Cell}^{-1}$ for carbon content was used (Lee \& Fuhrman 1987). Archaea have been reported to constitute significant fractions of Antarctic picoplankton assemblages (DeLong et al. 1994). These prokaryotes cannot be distinguished from bacteria with the flow cytometric method used; therefore, the terms bacterial abundance and bacterial biomass may include both Bacteria and Archaea.

\section{Depth integration}

All depth averages were calculated using the following equation:

$$
I=\frac{\sum_{i=1}^{n-1} \Delta Z_{i, i+1} 0.5\left(B_{i}+B_{i+1}\right)}{\sum_{i=1}^{n-1} \Delta Z_{i, i+1}}
$$

where $I$ denotes a sample level number (in increments from 1 at the sea-surface), $B_{i}$ denotes the concentration $\left(\mu \mathrm{g} \mathrm{C}^{-1}\right)$ measured at this sample level, and $\Delta Z_{i, j+1}$ is the thickness (m) of the layer between sequential sampling depths. Depth-averaged concentrations are reported as $\mu \mathrm{g} \mathrm{Cl} \mathrm{l}^{-1}$.

\section{Statistical analysis}

All statistical analysis of data was conducted using Microsoft Excel ${ }^{\circledR}$. Data were compared by either Pearson's correlation analysis, analysis of variance or regression analysis.

\section{RESULTS}

\section{The oceanographic environment and depth zones}

All CTD casts were made south of the Polar Front in an area where surface waters were categorised as Antarctic Surface Water, being typically warm for the region (up to $2.0^{\circ} \mathrm{C}$ ) and fresher $(<34.5)$ than the deeper waters from which they were formed due to solar heating during summer and ice melt (Orsi \& Wiederwohl 2009). Water mass characteristics showed some changes with depth, but the depth analysis of data presented in the present paper was based on the epipelagic zone (euphotic), mesopelagic and bathypelagic depths. The epipelagic zone was usually deeper than the MLD, except at shelf 
Sites C3 and C4 (Table 2). Average epipelagic zone depth was lowest in shelf waters at $38 \mathrm{~m}$, followed by seamounts at $80 \mathrm{~m}$, with slope and abyss waters having similar average depths of 88 and $89 \mathrm{~m}$, respectively.

\section{Spatial and vertical variation in phytoplankton and nutrients}

Late summer chl a concentrations were highest over the Ross Sea Shelf, reaching $1.3 \mathrm{mg} \mathrm{m}^{-3}(\mathrm{C} 4)$ in the strongly stratified surface waters and having an average of $0.7 \mathrm{mg} \mathrm{m}^{-3}$ in the epipelagic zone (Fig. 2). At the slope stations, chl a values reached a maximum of $0.5 \mathrm{mg} \mathrm{m}^{-3}$ and an average of $0.3 \mathrm{mg} \mathrm{m}^{-3}$ in the epipelagic zone. At both shelf and slope sites, chl a concentrations sharply decreased to almost 0 below $200 \mathrm{~m}$. The seamount stations had similar average concentrations of chl $a$, with a maximum of $0.5 \mathrm{mg} \mathrm{m}^{-3}$ and an average of $0.3 \mathrm{mg} \mathrm{m}^{-3}$ in the epipelagic zone (Fig. 2). Abyss sites were more variable, with chl a detected to a depth of 250 to $300 \mathrm{~m}$.

Late summer phytoplankton composition in the epipelagic zone of the Ross Sea was largely dominated by diatoms including Chaetoceros, Asterionella, Melosira, Asteromphalus Dactyliosolen, Probosci and Fragilariosis spp. (Chang et al. in press). There were 2 exceptions, with the prymnesiophyte Phaeocystis dominating biomass at shelf Site C4 (Chang et al. in press). Also, Pyramimonas sp. and dinoflagellates were abundant at Site C34 (Chang et al. in press).

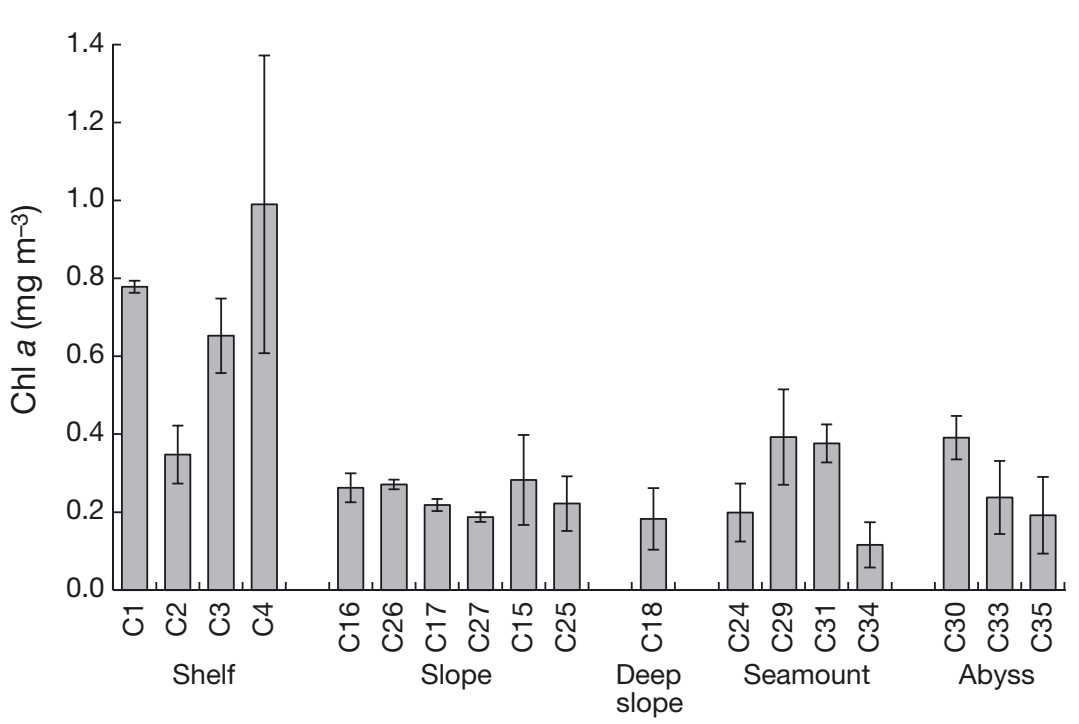

Fig. 2. Average chlorophyll a $\left(\mathrm{mg} \mathrm{m}^{-3}\right)$ in epipelagic waters at sites grouped by area - shelf, slope, deep slope, seamount and abyss - surveyed during the NZ IPY-CAML voyage to the Ross Sea region, 12 February to 11 March 2008. Error bars are $\pm 1 \mathrm{SD}$
Nitrate concentrations were never limiting, with values $>0.65 \mu \mathrm{M}$ throughout the survey. $\mathrm{NH}_{4}-\mathrm{N}$ concentrations were highest around $\sim 76^{\circ} \mathrm{S}$ in shelf waters and were statistically correlated with chl $a(\mathrm{r}=$ 0.40, $\mathrm{n}=196, \mathrm{p}<0.0001)$.

\section{Ciliate and small mesozooplankton composition}

Ciliate composition in the epipelagic zone was usually dominated by large non-loricate ciliates $(>20 \mu \mathrm{m})$, while at the high biomass shelf and selected seamount sites, tintinnids were also occasionally abundant (Table 3). Small oligotrichs $(<20 \mu \mathrm{m})$ were more important in epipelagic waters at low biomass abyss and slope sites. In the deeper mesopelagic and bathypelagic waters, smaller oligotrichs increased in importance, while larger ciliate genera consistently declined. A number of genera were only reported in epipelagic waters, while in deeper waters, the tintinnids Salpingella spp. and Amphorella spp. often increased in importance (Table 3).

Spatially compositional differences in both oligotrich and tintinnid populations occurred. The oligotrich genus Strobilidium $(>20 \mu \mathrm{m})$ and larger (>60 $\mu \mathrm{m}$ ) unidentified round oligotrichs dominated in epipelagic waters at most sites and were especially important on the shelf (Table 4). Tintinnids also varied among areas, with Cymatocylis, Laackmanniella spp. and Codonellopsis spp. dominating at high biomass shelf and seamount sites (Table 3).

The small mesozooplankton $(<200 \mu \mathrm{m}$, miscellaneous species) identified during ciliate counts were dominated by nauplii and showed no significant trends in composition with depth. Spatially, the highest diversity for this group was in the slope sites (Table 3), while biomass was again highest in shelf waters (Table 4) and lowest in slope and abyss sites. Proportionally small mesozooplankton declined at a lower rate with depth than ciliates in most areas (Table 4).

\section{Heterotrophic nanoflagellate and heterotrophic dinoflagellate composition}

Across our study areas and with depth, we found a wide range of HNF genera, a number of which we could not accu- 
Table 3. Average ciliate depth-integrated (Eq. 1) biomass ranges reported as $\mu \mathrm{g} \mathrm{C} \mathrm{l}^{-1}$ for all sites grouped by area (shelf 200-1200 m; slope, separated into West slope 600-2000 m, central (shallow) slope 400-600 m and deep slope 2000-2500 m; seamount 400-3000 m; and abyss 2800-3500 m) surveyed during the NZ IPY-CAML voyage to the Ross Sea region, 12 February to 11 March 2008. nd: not detected; Y = observed, but ranges of biomass are not given for miscellaneous species

\begin{tabular}{|c|c|c|c|c|c|c|}
\hline $\begin{array}{l}\text { Ciliate Group/ } \\
\text { Genera/Species }\end{array}$ & $\begin{array}{c}\text { Shelf } \\
(\mathrm{C} 1-4)\end{array}$ & $\begin{array}{c}\text { West slope } \\
\text { (C16-17, } \\
26-27)\end{array}$ & $\begin{array}{l}\text { Central slope } \\
(\mathrm{C} 15,25)\end{array}$ & $\begin{array}{l}\text { Deep slop } \\
\text { (C18) }\end{array}$ & $\begin{array}{c}\text { Seamount } \\
\text { (C24, C29, C31, } \\
\text { C32, C34) }\end{array}$ & $\begin{array}{c}\text { Abyss } \\
(\mathrm{C} 30, \mathrm{C} 33, \mathrm{C} 35)\end{array}$ \\
\hline \multicolumn{7}{|l|}{ Oligotrichs } \\
\hline Unid. Oligotrichia spp. $<20 \mu \mathrm{m}$ & $2-5.3$ & $2.8-3.6$ & $1.5-3.6$ & 1.1 & $1.4-5.8$ & $1.6-2.7$ \\
\hline Unid. Oligotrichia spp. $>20 \mu \mathrm{m}$ & $0.8-2.1$ & $0.4-0.5$ & $0.3-0.5$ & 0.2 & $0.2-1.2$ & $0.2-0.5$ \\
\hline Strombidium spp. $>20 \mu \mathrm{m}$ & $0-0.4$ & $0.1-0.2$ & $0-0.6$ & nd & $0-0.6$ & $0.1-0.2$ \\
\hline Strombidium spp. $<20 \mu \mathrm{m}$ & $<0.1$ & nd & $0-0.1$ & $<0.1$ & $0-<0.1$ & nd \\
\hline Strobilidium spp. $<20 \mu \mathrm{m}$ & $0.1-0.2$ & $0.2-0.3$ & $0.2-0.4$ & 0.1 & $0.2-0.4$ & $0.2-0.3$ \\
\hline Strobilidium spp. $>20 \mu \mathrm{m}$ & $2.2-5.9$ & $1.4-1.5$ & $0.4-1.3$ & 0.4 & $0.5-3.6$ & $0.8-1.2$ \\
\hline Strobilidium spp. (curved) & $0-<0.1$ & nd & $0-0.1$ & nd & $0-<0.1$ & nd \\
\hline Lohmaniella spiralis & $1.0-4.2$ & $1.5-1.9$ & $0.6-2.1$ & 0.5 & $0.8-3.4$ & $0.6-1.6$ \\
\hline Mesodinium spp. & $<0.1$ & nd & $0<0.1$ & nd & nd & $0-<0.1$ \\
\hline Didinium spp. & $0-0.4$ & nd & 0.0 .1 & nd & $0-0.7$ & $0-0.6$ \\
\hline Large spp. $>60 \mu \mathrm{m}$ round shape & $2.8-13.4$ & $0.4-7.8$ & $0.6-2.5$ & 0.7 & $0.7-5.1$ & $1.0-2.3$ \\
\hline Large spp. $>60 \mu \mathrm{m}$ cone shape & $0.9-1.8$ & $0.3-1.8$ & $0.6-1.0$ & 0.4 & $0.6-1.3$ & $0.2-0.7$ \\
\hline Laboea spp. & $0.2-30$ & $0.1-0.2$ & $0-<0.1$ & $<0.1$ & 0.1 & $0-0.6$ \\
\hline Laboea strobila & $0.6-13.1$ & $0.6-3.4$ & $0.3-2.5$ & 0.3 & $0-1.6$ & $1.0-2.3$ \\
\hline Tontonia spp. & $0.1-0.3$ & $0-<0.1$ & $0-<0.1$ & $<0.1$ & $0-0.3$ & $0-0.7$ \\
\hline cf. Kentrophyllum? & $0-30.7$ & $0-0.1$ & $0-0.1$ & nd & $0-0.3$ & $0-0.3$ \\
\hline \multicolumn{7}{|l|}{ Tintinnids } \\
\hline Amphorella spp. & $0-3.9$ & $0-0.2$ & $0-0.8$ & $<0.1$ & $0.1-2.3$ & $0.1-2.0$ \\
\hline Amphorellopsis spp. & $0-7.6$ & nd & nd & nd & nd & nd \\
\hline Codonella spp. & $0-0.1$ & nd & nd & nd & nd & nd \\
\hline Codonellopsis cf. gaussi & $0-5.8$ & $0-<0.1$ & nd & nd & $0.1-5.1$ & $0.8-2.4$ \\
\hline Codonellopsis cf. gaussi (small) & $0-0.3$ & nd & $0-0.1$ & nd & nd & nd \\
\hline Coxliella spp. & $0-<0.1$ & nd & nd & nd & nd & nd \\
\hline Cymatocylis cf. drygalskii & $1.3-31.9$ & 1.7 & $0-1.9$ & 0.4 & $0-8.7$ & nd \\
\hline Cymatocylis cf. vanhöffeni & $0-9.6$ & nd & nd & nd & nd & nd \\
\hline cf. Epiplocylis spp. & nd & nd & nd & nd & nd & $0-0.2$ \\
\hline Favella spp. & $0-0.1$ & nd & $0-0.9$ & nd & $0-0.9$ & nd \\
\hline Laackmanniella cf. naviculaefera & $0.3-8.1$ & $0-0.1$ & $0-0.2$ & nd & $0-0.7$ & $0.1-0.7$ \\
\hline Parundella spp. & $0-0.1$ & nd & nd & nd & nd & nd \\
\hline Salpingella spp. & $0-0.9$ & $0-0.1$ & $0-0.1$ & 0.1 & $0-1.2$ & $0-0.3$ \\
\hline Tintinnus spp. & nd & $0-<0.1$ & nd & nd & nd & nd \\
\hline Cymatocylis cf. convallaria & nd & nd & nd & nd & $0-0.4$ & $0-0.6$ \\
\hline cf. Ormosella spp. & nd & nd & nd & nd & $0-0.1$ & nd \\
\hline cf. Steenstrupiella spp. & nd & $0-<0.1$ & nd & nd & nd & nd \\
\hline \multicolumn{7}{|l|}{ Miscellaneous } \\
\hline Copepoda: adults & $\mathrm{Y}$ & $\mathrm{Y}$ & $\mathrm{Y}$ & $\mathrm{Y}$ & nd & $\mathrm{Y}$ \\
\hline Copepoda: copepodites & $\mathrm{Y}$ & $\mathrm{Y}$ & $\mathrm{Y}$ & nd & $\mathrm{Y}$ & $\mathrm{Y}$ \\
\hline Nauplii & $\mathrm{Y}$ & $\mathrm{Y}$ & $\mathrm{Y}$ & Y & $\mathrm{Y}$ & $\mathrm{Y}$ \\
\hline Appendicularians & $\mathrm{Y}$ & $\mathrm{Y}$ & $\mathrm{Y}$ & $\mathrm{Y}$ & $\mathrm{Y}$ & $\mathrm{Y}$ \\
\hline Polychaete larvae & nd & $\mathrm{Y}$ & nd & nd & nd & nd \\
\hline
\end{tabular}

rately identify due to preservation and which had to be classed by size (Table 5). In epipelagic zone waters, $<20 \mu \mathrm{m}$ heterotrophic dinoflagellates, although rarely numerically dominant, often dominated HNF biomass due to their larger average size, especially when phytoplankton biomass was high. Heterotrophic $<20 \mu \mathrm{m}$ dinoflagellates were dominated by small non-thecate genera, including Gymno- dinium spp., Gyrodinium spp. and some Katodinium spp., with Oxytoxum as the dominant thecate genus. In contrast, kinetoplastids, choanoflagellates and unidentified small genera dominated when biomass was low (especially at slope and abyss sites) and in the deeper mesopelagic and bathypelagic waters. Larger, > $20 \mu \mathrm{m}$ heterotrophic dinoflagellates were only important in epipelagic waters and contributed 
Table 4. Depth-integrated ciliate (and miscellaneous non-ciliate) numbers and ciliate biomass across areas - shelf, slope, seamount and abyss - over epipelagic (33-118 m), mesopelagic (118-1000 m) and bathypelagic (>1000 m) depth ranges surveyed during the NZ IPY-CAML voyage to the Ross Sea region, 12 February to 11 March 2008

\begin{tabular}{|c|c|c|c|c|c|c|c|c|c|}
\hline & $\begin{array}{l}\text { Miscellaneous } \\
\text { non-ciliates } \\
\left(\text { no. } 1^{-1}\right)\end{array}$ & $\begin{array}{l}\text { Oligotrichs } \\
\leq 20 \mu \mathrm{m} \\
\left(\text { no. } \mathrm{I}^{-1}\right)\end{array}$ & $\begin{array}{l}\text { Oligotrichs } \\
>20 \mu \mathrm{m} \\
\left(\text { no. } \mathrm{l}^{-1}\right)\end{array}$ & $\begin{array}{c}\text { Tintinnids } \\
\left(\text { no. } 1^{-1}\right)\end{array}$ & $\begin{array}{c}\text { Total } \\
\text { ciliates } \\
\left(\text { no. } 1^{-1}\right)\end{array}$ & $\begin{array}{l}\text { Oligotrichs } \\
\leq 20 \mu \mathrm{m} \\
\left(\mu \mathrm{g} \mathrm{Cl}^{-1}\right)\end{array}$ & 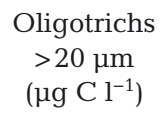 & $\begin{array}{l}\text { Tintinnid } \\
\text { biomass } \\
\left(\mu \mathrm{C}^{-1}\right)\end{array}$ & $\begin{array}{c}\text { Total ciliate } \\
\text { biomass } \\
\left(\mu g \mathrm{C}^{-1}\right)\end{array}$ \\
\hline \multicolumn{10}{|l|}{ Epipelagic } \\
\hline Shelf & 10 & 1472 & 858 & 251 & 2581 & 0.6 & 7.9 & 2.6 & 11.2 \\
\hline Slope & 3 & 1198 & 210 & 27 & 1435 & 0.5 & 1.3 & 0.3 & 2.0 \\
\hline Seamount & 4 & 1630 & 343 & 161 & 2133 & 0.8 & 2.0 & 1.4 & 4.2 \\
\hline Abyss & 3 & 1061 & 201 & 145 & 1407 & 0.4 & 1.2 & 0.8 & 2.4 \\
\hline \multicolumn{10}{|c|}{ Mesopelagic } \\
\hline Shelf & 1.5 & 534 & 217 & 21 & 771 & 0.2 & 1.1 & 0.5 & 1.9 \\
\hline Slope & 1.3 & 223 & 34 & 2 & 260 & 0.1 & 0.2 & 0.0 & 0.4 \\
\hline Seamount & 1.4 & 177 & 31 & 6 & 215 & 0.1 & 0.2 & 0.1 & 0.3 \\
\hline Abyss & 0.8 & 104 & 14 & 3 & 120 & 0.0 & 0.1 & 0.0 & 0.2 \\
\hline \multicolumn{10}{|c|}{ Bathypelagic } \\
\hline Slope & 0.0 & 69 & 2.3 & 0.1 & 71 & 0.03 & 0.02 & 0.00 & 0.05 \\
\hline Seamount & 0.3 & 20 & 1.0 & 0.0 & 21 & 0.01 & 0.00 & 0.00 & 0.01 \\
\hline Abyss & 0.1 & 16 & 0.8 & 0.1 & 16 & 0.01 & 0.00 & 0.00 & 0.01 \\
\hline
\end{tabular}

most in shelf and abyss sites, while their contribution was lowest in the slope sites (Fig. 3). A rapid decline in all heterotrophic dinoflagellates with depth meant that they were rarely seen beyond $200 \mathrm{~m}$. As depth increased and smaller non-dinoflagellate HNF genera became dominant, however, especially at depth, many could not be identified and were grouped only by size (Table 4).

Phytoplankton data for dinoflagellates as reported by Chang et al. (in press) indicate that the majority of dinoflagellates reported during this voyage were heterotrophic, contributing $95.4 \%$ of dinoflagellate cell carbon over the Ross Sea shelf area and 82 to $98 \%$ in the slope, abyss and seamount zones (Chang et al. in press).

Spatially in the epipelagic zone, we found our identified HNF genera changed their ratio of abundance rather than the absence or presence of new genera; however, in slope sites, the genus Telonema was absent and dinoflagellate diversity was at its lowest, while the choanoflagellate Monosiga was only observed at some abyss and seamount sites. At depth, the occurrence of smaller $(<8 \mu \mathrm{m})$ unidentifiable mono and biflagellate cells increased.
Table 5. Heterotrophic nanoflagellates and autotrophic nanoflagellates observed during the NZ IPY-CAML voyage to the Ross Sea region, 12 February to 11 March 2008

\begin{tabular}{|c|c|}
\hline Class/size class & Genus/species \\
\hline \multicolumn{2}{|c|}{ Heterotrophic nanoflagellates (including dinoflagellates) } \\
\hline \multirow[t]{5}{*}{ Kinetoplastids } & Bodo spp. \\
\hline & Pseudobodo spp. \\
\hline & cf. Pleurostomum \\
\hline & Telonema sp. \\
\hline & Leucocrytos marina (Braarud) \\
\hline \multirow[t]{3}{*}{ Choanoflagellatea } & Calliacantha natans (Grøntved) \\
\hline & Pleurasiga sp. \\
\hline & Monosiga sp. \\
\hline \multirow[t]{4}{*}{ Dinophyceae } & Oxytoxum spp. \\
\hline & Gymnodinium spp. \\
\hline & Gyrodinium spp. \\
\hline & Katodinium sp. \\
\hline$<2 \mu \mathrm{m}$ & Unidentified \\
\hline 2 to $5 \mu \mathrm{m}$ & Unidentified \\
\hline 5 to $20 \mu \mathrm{m}$ & Unidentified \\
\hline \multicolumn{2}{|c|}{ Autotrophic nanoflagellates (including dinoflagellates) } \\
\hline \multirow[t]{3}{*}{ Prymnesiophyceae } & Phaeocystis antarctica (Karst) \\
\hline & Phaeocystis spp. \\
\hline & Chrysochromulina spp. \\
\hline \multirow[t]{2}{*}{ Cryptophyceae } & Cryptomonas spp. \\
\hline & Plagioselmis sp. \\
\hline \multirow[t]{4}{*}{ Dinophyceae } & Oxytoxum spp. \\
\hline & Gymnodinium spp. \\
\hline & Gyrodinium spp. \\
\hline & Katodinium sp. \\
\hline Prasinophyceae & Pyramimonas spp. \\
\hline Pedinophyceae & Micromonas sp. \\
\hline Euglenophyceae & Eutreptiella sp. \\
\hline$<2 \mu \mathrm{m}$ & Unidentified \\
\hline 2 to $5 \mu \mathrm{m}$ & Unidentified \\
\hline 5 to $20 \mu \mathrm{m}$ & Unidentified \\
\hline
\end{tabular}




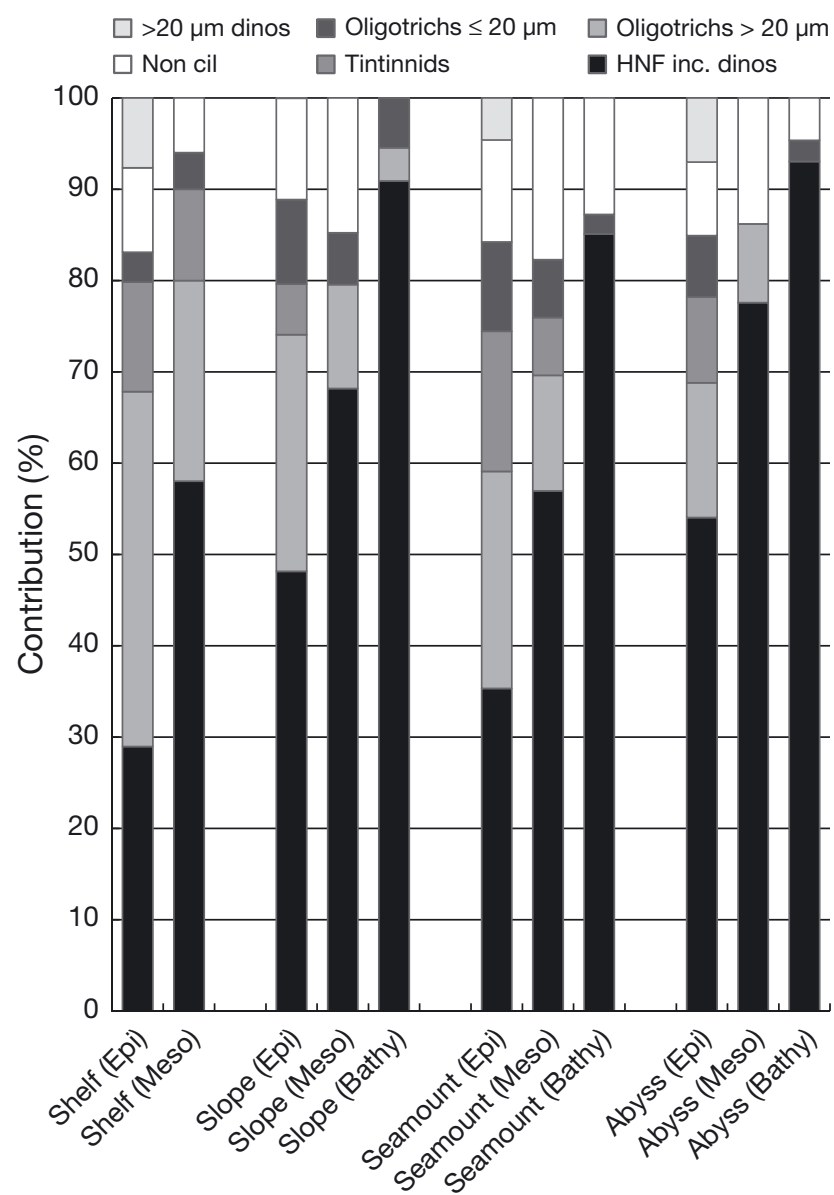

Fig. 3. Depth-integrated percentage contributions to total microzooplankton biomass of heterotrophic nanoflagellates (HNF) including heterotrophic dinoflagellates (dinos) $<20 \mu \mathrm{m}$, oligotrichs $>20 \mu \mathrm{m}$, tintinnids, oligotrichs $\leq 20 \mu \mathrm{m}$, nonciliated miscellaneous species (Non cil) and heterotrophic dinoflagellates $>20 \mu \mathrm{m}$. Epipelagic, mesopelagic and bathypelagic waters in 4 areas-shelf, slope, seamount and abyss - were surveyed during the NZ IPY-CAML voyage to the Ross Sea region, 12 February to 11 March 2008

\section{ANF and autotrophic dinoflagellate composition}

ANF diversity declined rapidly with depth, and the ANF identified by the presence of chloroplasts could not be distinguished from mixotrophs (autotrophs capable of grazing) in our study. ANF included representatives of Prymnesiophyceae, Cryptophyceae, Prasinophyceae, Pedinophyceae, Dinophyceae and Euglenophyceae (Table 5). The $>20 \mu \mathrm{m}$ autotrophic dinoflagellate biomass was very low, with on average $90 \%$ of dinoflagellate biomass being heterotrophic as reported by Chang et al. (in press). ANF including $<20 \mu \mathrm{m}$ autotrophic dinoflagellates contributed the most to larger phytoplankton biomass at Sites C18 (deep slope), C24 (seamount) and C33 (abyss).

\section{Changes in microzooplankton biomass spatially and with depth}

Ciliate biomass always peaked in the epipelagic or upper mesopelagic zone, with maxima between 20 and $150 \mathrm{~m}$ (usually $\geq 70 \mathrm{~m}$ ) (Table 4). Ciliates declined most rapidly at shelf sites, falling below detection at between $250 \mathrm{~m}$ and $835 \mathrm{~m}$. In contrast, at the deep abyss site C35, very low ciliate numbers were reported at $3385 \mathrm{~m}$ (Table 4 ). In the epipelagic zone, ciliate numbers $\left(\mathrm{l}^{-1}\right)$ were on average $\sim 4$-fold higher than in the mesopelagic zone and 200-fold higher than in the bathypelagic (Table 4).

Ciliate biomass also varied spatially (Table 4). Shelf sites had the highest ciliate biomass in epipelagic waters (Table 4 ), with maxima ranging between $6.5 \mu \mathrm{g} \mathrm{C}{ }^{-1}$ at $\mathrm{C} 2(20 \mathrm{~m})$ and $41 \mu \mathrm{g} \mathrm{C}{ }^{-1}$ at $\mathrm{C} 4$ $(20 \mathrm{~m})$. Slope sites had the lowest average biomass (Table 4), with peaks at $\sim 3 \mu \mathrm{C}^{-1}$, except C18, where the biomass maximum was only $0.9 \mu \mathrm{g} \mathrm{C} \mathrm{l}^{-1}$. The seamount sites peaked between 3.4 and $8.4 \mu \mathrm{g}$ $\mathrm{C}^{-1}$ between 20 and $70 \mathrm{~m}$, while abyssal sites peaked between 3.9 and $4.7 \mu \mathrm{C} \mathrm{C}^{-1}$ between 20 and $50 \mathrm{~m}$ (Table 4).

Spatially and with depth, HNF biomass was more variable than that of ciliates (Table 5). HNF overall declined at a much lower rate with depth than ciliates (Table 6), and at depths below the epipelagic zone, especially in the upper mesopelagic waters, the biomass and numbers of HNF remained relatively high at $\sim 3 \mu \mathrm{g} \mathrm{Cl}^{-1}$, while even at depths of $400 \mathrm{~m}$ and below, biomass was between 0 and $1.0 \mu \mathrm{g} \mathrm{C}^{-1}$ (with tens of cells $\mathrm{ml}^{-1}$ reported) (Table 6). In the epipelagic zone, HNF biomass was 2 -fold higher on average than in the mesopelagic zone and 6-fold higher than in the bathypelagic (Table 6).

Biomass was again highest on average at shelf sites, with maxima of 5.8 and $3.9 \mu \mathrm{g} \mathrm{C} \mathrm{l}^{-1}$ at shelf Sites C3 (70 m) and C4 (250 m), respectively, while the highest variability occurred at slope sites, having both the highest biomass of $9.7 \mu \mathrm{g} \mathrm{C} \mathrm{l}^{-1}$ at Site C17 (5 m) and a low biomass peak at Site C18 (50 m) of only $1.6 \mu \mathrm{g} \mathrm{C} \mathrm{l}^{-1}$. Low biomass seamount sites peaked at $4 \mu \mathrm{g} \mathrm{C} \mathrm{l}^{-1}(100 \mathrm{~m})$ at Site C24, while Site C34 peaked at only $1.3 \mu \mathrm{g} \mathrm{C} \mathrm{l}^{-1}(10 \mathrm{~m})$, the lowest of the study. Epipelagic abyssal waters were similar to slope sites on average (Table 6) but had a maximum of $8.92 \mu \mathrm{g} \mathrm{C} \mathrm{l}^{-1}$ reported at Site C35 (5 m).

ANF rapidly dropped to near detection levels below 100 to $150 \mathrm{~m}$ in the seamount sites but were occasionally reported as deep as $1000 \mathrm{~m}$ in slope and abyssal sites. 
Table 6. Depth-integrated (Eq. 1) heterotrophic nanoflagellate (HNF) and autotrophic nanoflagellate (ANF) numbers and biomass (including dinoflagellates) observed across each of 4 areas - shelf, slope, seamount and abyss - over epipelagic (33-118 m), mesopelagic (118-1000 m) and bathypelagic $(>1000 \mathrm{~m})$ depth ranges surveyed during the NZ IPY-CAML voyage to the Ross Sea region, 12 February to 11 March 2008

\begin{tabular}{|lcccc|}
\hline & $\begin{array}{c}\text { ANF } \\
\left(\text { cells ml }^{-1}\right)\end{array}$ & $\begin{array}{c}\text { ANF } \\
\left(\mu \mathrm{C} \mathrm{C}^{-1}\right)\end{array}$ \\
\hline Epipelagic & & & & \\
Shelf & 667 & 464 & 3.6 & 4.6 \\
Slope & 412 & 373 & 1.5 & 2.6 \\
Seamount & 271 & 499 & 1.0 & 2.2 \\
Abyss & 271 & 351 & 1.5 & 3.5 \\
Mesopelagic & & & & \\
Shelf & 492 & 277 & 2.0 & 2.9 \\
Slope & 82 & 153 & 0.3 & 1.2 \\
Seamount & 53 & 130 & 0.2 & 0.9 \\
Slope & 17 & 102 & 0.1 & 0.5 \\
Bathypelagic & & & & \\
Seamount & 0 & 42 & 0.0 & 0.4 \\
Slope & 0 & 89 & 0.0 & 0.4 \\
Abyss & 0 & 51 & 0.0 & 0.9 \\
\hline
\end{tabular}

\section{Change in the contribution of different microzooplankton groups spatially and with depth}

Ciliates were more important in the epipelagic zone and decreased in importance with depth (Fig. 3). In contrast, HNF clearly dominated in the mesopelagic and bathypelagic zones across all sites. Heterotrophic dinoflagellates were most important in the epipelagic zone, where both large $(>20 \mu \mathrm{m})$ and small cells (incl. $<20 \mu \mathrm{m}$ HNF) made an important contribution. Small miscellaneous mesozooplankton did not change significantly in their contribution to total biomass with depth, with the exception of bathypelagic slope waters (Fig. 3). Spatially, in epipelagic waters, ciliates dominated microzooplankton biomass at shelf and seamount sites, whereas at abyssal and slope sites, HNF dominated (Fig. 3). There were 2 sites where the microzooplankton composition was inconsistent with our general observations. Slope site C15 had high ciliate biomass but low contributions from other microzooplankton. In contrast, Site C17 was distinct from all other sites as it had an unusually high HNF biomass in epipelagic waters.

\section{Correlation analysis between microzooplankton and known prey populations}

Across all sites, we found ciliate populations in the epipelagic zone were most significantly correlated (based on r-values) with chl a followed by bacterial populations, eukaryotic picophytoplankton (EPICO) and ANF. Small oligotrichs $\leq 20 \mu \mathrm{m}$ were most highly correlated to EPICO, while large oligotrichs $>20 \mu \mathrm{m}$ and tintinnids were highly correlated with ANF (Table 7). Across all sites, HNF biomass was not significantly correlated with bacteria or EPICO but was correlated with small $(\leq 20 \mu \mathrm{m})$ and large $(>20 \mu \mathrm{m})$ oligotrich biomass (Table 7 ). When areas were analysed separately, HNF numbers were significantly correlated with EPICO and bacteria but only in shelf sites (Table 7).

\section{Changes in the relationship between microzooplankton groups and bacteria with depth}

The ratio of depth-integrated ciliate biomass, HNF populations and bacteria varied among our depth zones (Fig. 4). Total integrated HNF and ciliate biomass in mesopelagic waters exceeded the total biomass found in the epipelagic zone. In the bathypelagic, this remained true for HNF biomass, but total ciliate biomass was low. In these deeper zones, the total integrated bacterial biomass also steadily increased with depth (Fig. 4). The ratio of integrated bacterial biomass to integrated microzooplankton biomass increased from a low of 0.4 in the epipelagic zone to 0.7 in the mesopelagic to 1.8 in the bathypelagic zone, indicating a reduction in the prey to predator ratio with depth. To compare our relative

Table 7. Epipelagic zone correlation coefficients (r) between selected microzooplankton biomass (ANF: autotrophic nanoflagellates, HNF: heterotrophic nanoflagellates) and their potential prey biomass ( $\mu \mathrm{g} \mathrm{C}^{-1}$ ) for epipelagic biomasses surveyed during the NZ IPY-CAML voyage to the Ross Sea region, 12 February to 11 March $2008 .{ }^{*} \mathrm{p}<0.05,{ }^{* *} \mathrm{p}<0.001$, $\mathrm{f}$ : only significantly correlated at shelf sites, ns: not significant

\begin{tabular}{|lcccc|}
\hline & $\begin{array}{c}\text { Eukaryotic pico- } \\
\text { phytoplankton }\end{array}$ & Bacteria & ANF & Chl $a$ \\
& $\mathrm{~ns}$ & $0.47^{*}$ & $\mathrm{~ns}$ & $0.76^{*}$ \\
$\mathrm{ANF}$ & $0.82^{* *}, \mathrm{f}$ & $0.57^{* *}, \mathrm{f}$ & $\mathrm{ns}$ & $\mathrm{ns}$ \\
$\mathrm{HNF}$ & $0.36^{* *}$ & $0.39^{* *}$ & $0.47^{*}$ & $0.47^{*}$ \\
Misc. non-ciliates & $0.54^{* *}$ & $0.38^{* *}$ & $\mathrm{~ns}$ & $\mathrm{~ns}$ \\
Oligotrichs $\leq 20 \mu \mathrm{m}$ & $0.45^{* *}$ & $0.50^{* *}$ & $0.31^{*}$ & $0.45^{*}$ \\
Oligotrichs $>20 \mu \mathrm{m}$ & $0.49^{* *}$ & $0.57^{* *}$ & $0.66^{* *}$ & $0.78^{* *}$ \\
Tintinnid biomass & $0.53^{* *}$ & $0.58^{* *}$ & $0.50^{*}$ & $0.58^{*}$ \\
Total ciliate biomass & $0.45^{* *}$ & $0.56^{* *}$ & $\mathrm{~ns}$ & $0.52^{* *}$ \\
Dinoflagellates $>20 \mu \mathrm{m}$ & & & & \\
\hline
\end{tabular}




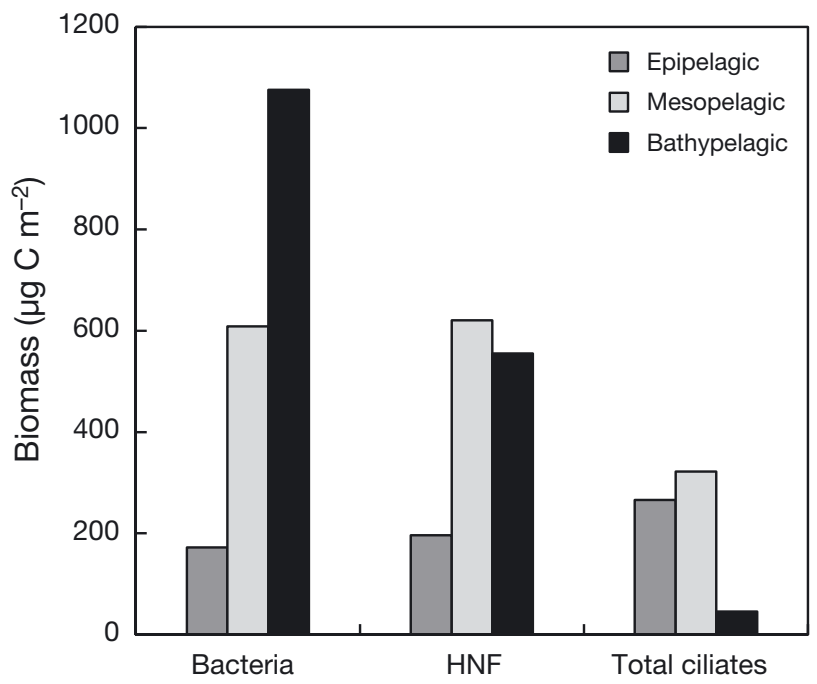

Fig. 4. Average total depth-integrated biomass for all sites of bacteria, HNF and ciliates in epipelagic, mesopelagic and bathypelagic zones surveyed during the NZ IPY-CAML voyage to the Ross Sea region, 12 February to 11 March 2008

rates of decline of these microbial food web components, we also examined the vertical attenuation rates of these populations across our entire study, as a linear regression slope of a log-log plot of biomass versus depth following the analysis method of Sohrin et al. (2010). The vertical attenuation rate of ciliate biomass was highest (linear slope), $y=-1.03\left(\mathrm{R}^{2}=\right.$ 0.68 ), while that of HNF was much lower at $y=-0.36$ but more variable and less robust $\left(\mathrm{R}^{2}=0.3\right)$ although more similar to that of bacteria, $y=-0.33\left(\mathrm{R}^{2}=0.51\right)$.

The integrated microzooplankton biomass found in deeper waters (Fig. 4) also exceeded that found in the epipelagic zone and consequently appears to be quantitatively significant in both mesopelagic and bathypelagic waters. Both ciliates and HNF increased in total biomass in the epipelagic, and while ciliates declined rapidly in the bathypelagic, bathypelagic HNF biomass still exceeded epipelagic biomass.

\section{DISCUSSION}

For the first time, the present study investigates changes in microzooplankton in the deeper mesopelagic and bathypelagic zones of the Ross Sea. The timing of this voyage in late summer (mid-February to mid-March) was also during the understudied period of transition between the autotrophic phytoplankton-dominated summer (November to February) and the heterotrophic grazer-dominated autumn (March to May) (Dennett et al. 2001). This, combined with the large depth range, variable topography and physical diversity among sampling areas, led to large variability in microbial assemblages.

Microzooplankton communities showed considerable variation both spatially and with depth (Tables 3 \& 5), being dominated by a range of heterotrophic protistan species including ciliated protozoa, HNF and heterotrophic dinoflagellates. All genera that could be identified were consistent with those previously reported in this region (Garrison \& Gowing 1993, Marchant \& Murphy 1994, Garrison et al. 1996, Scott \& Marchant 2005).

\section{Microzooplankton and the microbial food web}

To understand changes occurring in deeper waters, we needed to first understand the oceanographic environment and the microbial patterns and processes occurring in the productive epipelagic zone. Phytoplankton populations at the time of the present study were dominated by diatoms, with the flagellated Phaeocystis antarctica and Pyramimonas spp. dominating at only 2 of our 18 sampling sites. This predominance of diatoms, especially in higher biomass sites, indicated that autotrophic processes more typical of summer than of the heterotrophic autumn were still operating in most epipelagic waters (Dennett et al. 2001). The microzooplankton composition reflected this, with larger ciliates dominating in highbiomass, diatom-dominated epipelagic waters, where HNF assemblages were often dominated by small dinoflagellates. In contrast, in low biomass sites and in deeper waters, bacterivorous flagellates including choanoflagellates, kinetoplastids and unidentified small species became increasingly important (Garrison et al. 1996, Caron et al. 1999, Dennett et al. 2001). Beyond the epipelagic zone, at depth, it was also likely that many of these smaller HNF were associated with sinking aggregates rather than free living (Kiørboe et al. 2004).

Spatial variation among our different areas generally reflected the different oceanographic influences and topography. Abyssal sites were low in phytoplankton biomass $\left(\sim 0.3 \mathrm{mg} \mathrm{m}^{-3}\right)$, were HNF dominated with elevated quantities of $>20 \mu \mathrm{m}$ dinoflagellates and had deep epipelagic zones (down to $118 \mathrm{~m}$ ) and deep mixed layers, all typical of Southern Ocean high nutrient, low chlorophyll waters (Hall \& Safi 2001). In contrast, near-shore shelf sites were generally shallower, with shallow mixed layers (30 to $90 \mathrm{~m}$ ), had relatively high phytoplankton biomass (up to $1.5 \mathrm{mg} \mathrm{m}^{-3}$ ) and were dominated by larger ciliates 
(although larger dinoflagellates were also elevated) in the epipelagic zone. Slope sites represented intermediate situations and were as such the most variable but were also the sites with the least $>20 \mu \mathrm{m}$ dinoflagellate biomass. The seamount sites, although influenced by shallower mixed layer depths and their proximity to land (e.g. Scott Island), were also highly variable due to the influence of surrounding waters and current flows.

Correlation analysis confirmed the general trends observed between microbial food web components in the epipelagic zone. Smaller ciliates (oligotrichs $\leq 20 \mu \mathrm{m}$ ) were most highly correlated with bacteria and EPICO, while larger ciliates (oligotrichs $>20 \mu \mathrm{m}$ and tintinnids) were more highly correlated with ANF and chl a. These results correspond to a size dependent grazing relationship for ciliates, as is widely reported elsewhere (Admiraal \& Venekamp 1986, Weisse \& Scheffel-Möser 1990, Foissner et al. 1991, Latasa et al. 1996, Landry et al. 2000). Larger heterotrophic dinoflagellates $(>20 \mu \mathrm{m})$ were also correlated with chl $a$, EPICO and bacteria, indicating these factors are likely to be influencing food web structure in the epipelagic zone.

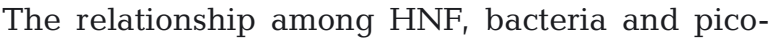
phytoplankton was highly variable (Table 6). A lack of a consistent correlation between HNF and these prey populations is, however, not uncommon (Landry et al. 2000, Safi et al. 2007) and is affected by the successional phase being sampled, competition with other microzooplankton predators and predation upon HNF by other grazers.

In the epipelagic (and some upper mesopelagic waters) competition with mixotrophic phytoplankton (autotrophic dinoflagellates and ANF) and predation by large ciliates and heterotrophic dinoflagellates are both likely to have affected grazer relationships, with these populations being elevated in epipelagic waters (Jacobson \& Anderson 1986, Strom \& Buskey 1993, Verity et al. 1993). One example of where dinoflagellates and autotrophic flagellates were both proportionately high in biomass and were likely to have influenced the food web structure was seamount site C34: at this site, both ciliate size and biomass were low compared to phytoplankton biomass.

\section{Deep water microzooplankton assemblages}

In terms of composition, as alluded to earlier, we consistently observed an increase in the importance of HNF, especially kinetoplastids, choanoflagellate and small unidentified flagellates, in deeper meso- pelagic and bathypelagic waters. In contrast, both small and large heterotrophic dinoflagellates declined rapidly with depth. We also observed that a number of the smaller flagellates, especially among the kinetoplastidae, appeared to be associated with (marine snow) aggregates, an observation consistent with other studies (Artolozaga et al. 2002, Kiørboe et al. 2004). Among the HNF genera, especially in bathypelagic waters, smaller unidentified species became increasingly important, as has also been reported elsewhere (Arndt et al. 2003, Not et al. 2007). Within ciliate populations, larger ciliates declined in importance, and bacterivorous oligotrichs $<20 \mu \mathrm{m}$ became increasingly dominant with depth. As larger ciliates declined with depth, so did carnivores, omnivores or species known to graze larger prey (Foissner et al. 1991, 1992, 1994). Similarly, the larger heterotrophic (and mixotrophic) dinoflagellates known to be capable of grazing larger prey also declined rapidly with depth. The loss of these populations was directly associated with the decline of phytoplankton prey, while smaller HNF and oligotrichs have a greater affinity for bacterial and detrital material and are known to colonise descending aggregates (Artolozaga et al. 2002, Kiørboe et al. 2004). Spatial changes in composition related to epipelagic waters only occurred in the upper mesopelagic zone; beyond these depths, due to the increasing importance of small unidentified HNF, we were unable to identify clear changes in terms of speciation.

\section{Microzooplankton biomass and rates of decline with depth}

Changes in microzooplankton groups with depth in other ocean environments are reported to be due to different microzooplankton populations declining at different rates (Tanaka \& Rassoulzadegan 2002, Nagata et al. 2010, Sohrin et al. 2010). Lower rates of decline in HNF compared to other microzooplankton groups are common and led to this group being the most abundant in our deeper waters, as has been reported previously in the Mediterranean, Pacific and Atlantic oceans (Tanaka \& Rassoulzadegan 2002, Nagata et al. 2010, Sohrin et al. 2010).

HNF, which had the slowest decline in numbers, ranged from below detection levels in the bathy-

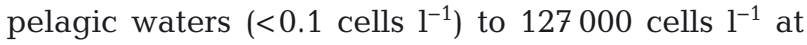
C18 at 1250 m. In comparison, Nagata et al. (2010) reported lower numbers in this zone of ca. 20 to 20000 cells $1^{-1}$. Although we found that ciliates 
declined more rapidly than HNF, they were still observed in the deeper mesopelagic and even in the upper bathypelagic zone, with a maximum value of

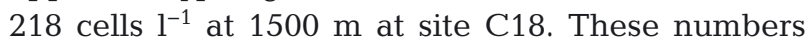
were high compared to other studies, with Nagata et al. (2010) reporting ciliate abundances in bathypelagic waters ranging from below the detection limit $\left(0.1\right.$ cells $\left.^{-1}\right)$ to only 52 cells $~^{-1}$. The decline in heterotrophic dinoflagellates was fast compared to both HNF and ciliates, with this group being largely limited to the upper mesopelagic zone (100 to $250 \mathrm{~m}$ ), as was reported in the Arabian Sea (Gowing et al. 2003).

We did find spatial differences in our rates of decline, but as with speciation these were largely limited to the epipelagic and upper mesopelagic waters and were linked to phytoplankton biomass. At the shallower shelf sites, which did not extend beyond the mesopelagic, all populations declined proportionately more rapidly with depth than in other areas, although these faster rates reflected the high surface biomass and shallow mixed layers, with absolute numbers on average higher at depth than reported in our other areas. In contrast, deep slope site C18 had consistently proportionately high numbers at depth, which did not reflect elevated surface concentrations. The higher numbers found at depth at this site may have been the result of higher export rates or export from a high surface population which existed prior to our arrival. At some sites, we also observed secondary peaks in HNF and ciliate numbers, usually in the upper mesopelagic but occasionally much deeper. In the upper mesopelagic, these may reflect an export zone where reduced competition allows HNF and occasionally ciliates to form a secondary peak. Ciliate populations also occasionally showed substantial peaks at substantial depths, which again appear linked to export events with other biological parameters also elevated at these depths (including POC and flagellates). Slope site C18 at $1500 \mathrm{~m}$ and seamount site C31 between 500 and $590 \mathrm{~m}$ are the best examples.

Our relatively high microzooplankton numbers (both ciliates and HNF) in deeper waters may also be linked to the timing of our voyage in late summer, following high summer phytoplankton biomasses (chl a concentrations up to $\sim 15 \mathrm{mg} \mathrm{m}^{-3}$ ) (Dennett et al. 2001). Some studies have suggested that although HNF can be described as a function of phytoplankton surface biomass, this may not incorporate export events, which will lead to higher abundances being observed at depth (Tanaka \& Rassoulzadegan 2002, Arístegui et al. 2005). It is also likely that some of the nanoflagellates we observed at depth are themselves part of the export process, as flagellates are known to bloom in the Ross Sea during summer (DiTullio \& Smith 1996, Arrigo et al. 1999).

Although biomass per unit volume is expected to be highest in epipelagic waters, it is also recognised that because deeper mesopelagic and bathypelagic waters represent larger volumes, the total biomass at depth could be significant and may even exceed that of the epipelagic zone (Nagata et al. 2010, Sohrin et al. 2010). When we integrated total microzooplankton biomass, the HNF biomass in the mesopelagic and bathypelagic exceeded that in the epipelagic zone, while ciliate biomass in the mesopelagic also exceeded that found in the epipelagic. The discovery of these large pools of biomass at depth indicates that HNF and ciliates are likely to play a significant role in the microbial loop at depth, both by grazing and repackaging carbon for larger zooplankton grazers. These processes will also aid in recycling of sinking carbon (detritus) for bacterial consumption through sloppy grazing and excretion.

The majority of prey available at depth, beyond the productive photic/epipelagic zone, is assumed to be either bacterial or detrital in nature. We focused on bacterial population changes at depth and compared their relative rate of decline to HNF, as these were the dominant populations in our deeper waters. Bacterial biomass increased proportionally to microzooplankton biomass with depth, a result consistent with previous reports in other deeper waters (Tanaka \& Rassoulzadegan 2002, Sohrin et al. 2010), including the subarctic. Sohrin et al. (2010) reported an HNF attenuation rate 1.7 -fold steeper than that of bacteria and suggested this could lead to an accumulation of bacteria at depth due to low grazing pressure. Our results were less conclusive, as our HNF attenuation rates were only 1.1-fold steeper than for bacteria, indicating a lower potential for accumulation in our system and a larger potential for grazing pressure on bacteria even at depth at the time of our study.

Further complicating the role of microzooplankton in mesopelagic and bathypelagic waters is predation by zooplankton, with reports that microzooplankton can represent up to $90 \%$ of the diet of some Ross Sea zooplankton (Lonsdale et al. 2000). This again has implications for the role of microzooplankton in carbon cycling at depth, as it has recently been suggested that zooplankton affect carbon export by transporting grazed organic matter across depth zones by diel vertical migration (Steinberg et al. 2008). Our results suggest that there is a significant population of microzooplankton at depth in the Ross 
Sea, and if this population is being grazed by zooplankton, there is potential for significant carbon transport back into the epipelagic zone. Overall, our results indicate that microzooplankton at depth may play an important role in both converting biomass (allowing remineralisation processes to occur) and repackaging biomass in a form available for larger, deep-water consumers.

\section{CONCLUSIONS}

Microzooplankton composition and biomass varied both among sites and with depth but usually reflected their available potential prey. In high-biomass, epipelagic waters, large phytoplankton and ciliates (and occasionally dinoflagellates) dominated, while in deeper waters (or low phytoplankton-biomass epipelagic zones), bacteria and HNF dominated. Deep microzooplankton populations, although similar, were often higher in abundance than those reported in other waters, indicating for the first time that during this summer-autumn transition period, the Ross Sea has a large pool of deep microzooplankton biomass. In deeper HNF-dominated waters, we found, as has been reported elsewhere, that the total integrated microzooplankton biomass exceeded that of the epipelagic zone. Our findings suggest that microzooplankton biomass in the Ross Sea during the summer autumn transition period is important not only in the epipelagic zone, as traditionally observed, but also in mesopelagic and bathypelagic waters. This group of organisms has the potential to aid in recycling and remineralisation of sinking biomass traditionally thought to be exported to the ocean floor.

Acknowledgements. This research was funded by the New Zealand Government under the NZ International Polar Year-Census of Antarctic Marine Life Project. We thank the officers, crew and scientific staff on RV 'Tangaroa'. We gratefully acknowledge project governance provided by the Ministry of Fisheries Science Team and the Ocean Survey 20/20 CAML Advisory Group (LINZ, MFish, Antarctica NZ, MFAT and NIWA). We also thank C. Stevens for critical comments on the manuscript.

\section{LITERATURE CITED}

- Admiraal W, Venekamp LAH (1986) Significance of tintinnid grazing during blooms of Phaeocystis pouchetii (Haptophyceae) in Dutch coastal waters. Neth J Sea Res 20:61-66

Alder VA (1999) Tintinnoinea. In: Boltovskoy D (1906) South Atlantic zooplankton Vol 1. Backhuys, Leiden, p 321-384 Alder VA, Boltovskoy D (1993) The ecology of larger micro- zooplankton in the Weddell-Scotia confluence area: horizontal and vertical-distribution patterns. J Mar Res 51: 323-344

Arístegui J, Agustí S, Middelburg JJ, Duarte CM (2005) Respiration in the mesopelagic and bathypelagic zones of the oceans. In: Del Giorgio PA, Williams PJleB (eds) Respiration in aquatic ecosystems. Oxford University Press, Oxford, p 181-205

Arndt H, Hausmann K, Wolf M (2003) Deep-sea heterotrophic nanoflagellates of the Eastern Mediterranean Sea: qualitative and quantitative aspects of their pelagic and benthic occurrence. Mar Ecol Prog Ser 256:45-56

Arrigo KR, Weiss AM, Smith WO Jr (1998) Physical forcing of phytoplankton dynamics in the southwestern Ross Sea. J Geophys Res 103:1007-1021

Arrigo KR, Robinson DH, Worthen DL, Dunbar RB, DiTullio GR, VanWoert M, Lizotte MP (1999) Phytoplankton community structure and the drawdown of nutrients and $\mathrm{CO}_{2}$ in the Southern Ocean. Science 283:365-367

Artolozaga I, Valcárcel M, Begoña A, Latatu A, Iriberri J (2002) Grazing rates of bacterivorous protists inhabiting diverse marine planktonic microenvironments. Limnol Oceanogr 47:142-150

Becquevort S (1997) Nanoprotozooplankton in the Atlantic sector of the Southern Ocean during early spring: biomass and feeding activities. Deep-Sea Res II 44:355-373

Beers JR, Stewart GL (1967) Microzooplankton in the euphotic zone at five locations across the California Current. J Fish Res Board Can 24:2053-2068

Booth BC (1988) Size classes and major taxonomic groups of phytoplankton at two locations in the subarctic ocean in May and August, 1984. Mar Biol 97:275-286

Brandt K (1906) Die Tintinnodeen der Plankton-Expedition. Ergebnisse der Plankton-Expedition der HumboldtStiftung. Bd III. L. a. Verlag von Lipsius \& Tischer, Kiel \& Leipzig

Brzezinski MA, Nelson DM, Franck VM, Sigmon DE (2001) Silicon dynamics within an intense open-ocean diatom bloom in the Pacific sector of the Southern Ocean. DeepSea Res II 48:3997-4018

Buesseler KO, Boyd PW (2009) Shedding light on processes that control particle export and flux attenuation in the twilight zone of the open ocean. Limnol Oceanogr 54: 1210-1232

Burkill PH, Edwards ES, Sleigh MA (1995) Microzooplankton and their role in controlling phytoplankton growth in the marginal ice zone of the Bellingshausen Sea. DeepSea Res I 42:1277-1290

Caron DA, Lonsdale DJ, Dennett MR (1999) Bacterivory and herbivory play key roles in the fate of Ross Sea production. Antarct J US 32:81-83

Caron DA, Dennett MR, Lonsdale DJ, Moran DM, Shalapyonok L (2000) Microzooplankton herbivory in the Ross sea, Antarctica. Deep-Sea Res II 47:3249-3272

Chang FH, Williams M, Schwarz J, Hall J, Gall M, Maas E, Stewart R (in press) Spatial variation of phytoplankton assemblages and biomass between New Zealand and the Ross Sea during the late austral summer 2008. Polar Biol

Chretiennot-Dinet M, Billard C, Sournia A (1990) Chorarachniophycees, Chlorophycees, Chrysophycees, Cryptophycees, Euglenophycees, Eustigmatophycees, Prasinophycees, Prymnesiophycees, Rhodophycees et Tribophycees. In: Sournia A (ed), Atlas du phytoplankton marin, Vol 3. Editions du CNRS, Paris, p 1-261 
Corliss JO (1961) The ciliated protozoa: characterization, classification and guide to the literature, 2nd edn. Pergamon Press, London, New York, NY

Cowley R, Critchley G, Eriksen RS, Latham V, Plaschke RB, Rayner MS, Terhell D (1999) Hydrochemistry operations manual. CSIRO Div Mar Res Tech Rep 236, Hobart

DeLong EF, Wu KY, Prezelin BB, Jovine RVM (1994) High abundance of Archaea in Antarctic marine picoplankton. Nature 371:695-697

$>$ Dennett MR, Mathot S, Caron DA, Smith WO Jr, Lonsdale DJ (2001) Abundance and distribution of phototrophic and heterotrophic nano- and microplankton in the southern Ross Sea. Deep-Sea Res II 48:4019-4037

DiTullio GR, Smith WO Jr (1996) Spatial patterns in phytoplankton biomass and pigment distributions in the Ross Sea. J Geophys Res 101:18467-18478

Edler L (1979) Recommendations on methods for marine biological studies in the Baltic Sea. Phytoplankton and chlorophyll. The Baltic Marine Biologists Publ No 5, Malmö

Fennel W, Neumann T (2003) Variability of copepods as seen in a coupled physical biological model of the Baltic Sea. ICES Mar Sci Symp 219:208-219

Foissner W, Blatterer H, Berger H, Kohmann F (1991) Taxonomische und Ökologische Revision der Ciliaten des Saprobiensystems. Band I: Cyrtophorida, Oligotrichida, Hypotrichida, Colpodea. Informationsberichte des Bayerischen Landesamtes für Wasserwirtschaft, Munich

Foissner W, Berger H, Kohmann F (1992) Taxonomische und Ökologische Revision der Ciliaten des Saprobiensystems. Band II: Peritrichia, Heterotrichida, Odontostomatida. Informationsberichte des Bayerischen Landesamtes für Wasserwirtschaft, Munich

Foissner W, Berger H, Kohmann F (1994) Taxonomische und Ökologische Revision der Ciliaten des Saprobiensystems. Band III: Hymenostomata, Prostomatida, Nassulida. Informationsberichte des Bayerischen Landesamtes für Wasserwirtschaft, Munich

$>$ Fonda Umani S, Monti M, Nuccio C (1998) Microzooplankton biomass distribution in Terra Nova Bay, Ross Sea, Antarctica. J Mar Syst 17:289-303

Garrison DL, Gowing MM (1993) Protozooplankton. In: Friedmann EI (ed) Antarctic microbiology. Wiley-Liss, New York, NY, p 123-165

Garrison DL, Mathot S, Gowing MM, Kunze H (1996) Phytoplankton and microzooplankton community structure in the Ross Sea polynya: November-December, 1994. EOS Trans Am Geophys Union 76:137 (Abstract)

Gowing MM, Garrison DL, Wishner KF, Gelfman C (2003) Mesopelagic microplankton of the Arabian Sea. DeepSea Res I 50:1205-1234

Hall JA, Safi KA (2001) The impact of in situ Fe fertilisation on the microbial food web in the Southern Ocean. DeepSea Res II 48:2591-2613

Hall JA, James MR, Bradford-Grieve JM (1999) Structure and dynamics of the pelagic microbial food web of the Subtropical Convergence region east of New Zealand. Aquat Microb Ecol 20:95-105

Hall JA, Safi KA, Cummings A (2004) Role of microzooplankton grazers in the subtropical and subantarctic waters to the east of New Zealand. NZ J Mar Freshw Res 38:91-101

Hoppenrath M, Elbrächter M, Drebes G (2009). Marine phytoplankton: selected microphytoplankton species from the North Sea around Helgoland and Sylt. E. Schweizerbart'sche Verlagsbuchhandlung, Stuttgart
Jacobson DM, Anderson DM (1986) Thecate heterotrophic dinoflagellates: feeding behaviour and mechanisms. J Phycol 22:249-258

Kiørboe T, Grossart HP, Ploug H, Tang K, Auer B (2004) Particle-associated flagellates: swimming patterns, colonization rates, and grazing on attached bacteria. Aquat Microb Ecol 35:141-152

Klaas C (1997) Microprotozooplankton distribution and their potential grazing impact in the Antarctic circumpolar current. Deep-Sea Res II 44:375-393

Kofoid CA, Campbell AS (1929) A conspectus of the marine and fresh-water ciliata belonging to the suborder Tintinnoinea, with descriptions of new species principally from the Agassiz expedition to the eastern tropical Pacific 1904-1905. Univ Calif Publ Zool 34:1-403

Kofoid CA, Campbell AS (1939) The Tintinnoinea of the eastern Tropical Pacific. Bull Mus Comp Zool Harvard Univ 84:1-473

> Landry MR, Selph KE, Brown SL, Abbott MR and others (2002) Seasonal dynamics of phytoplankton in the Antarctic Polar Front region at $170^{\circ} \mathrm{W}$. Deep-Sea Res II 49: 1843-1865

- Landry MR, Constantinou J, Latasa M, Brown SL, Bidigare RR, Ondrusek ME (2000) Biological response to iron fertilization in the eastern equatorial Pacific (IronEx II). III. Dynamics of phytoplankton growth and microzooplankton grazing. Mar Ecol Prog Ser 201:57-72

> Latasa M, Bidigare RR, Ondrusek ME, Kennicut MC (1996) HPLC analysis of algal pigments: a comparison exercise among laboratories and recommendation for improved analytical performance. Mar Chem 51:315-324

> Lebaron P, Parthuisot N, Catala P (1998) Comparison of blue nucleic acid dyes for flow cytometric enumeration of bacteria in aquatic systems. Appl Environ Microbiol 64: 1725-1730

Lee S, Fuhrman JA (1987) Relationships between biovolume and biomass of naturally derived marine bacterioplankton. Appl Environ Microbiol 53:1298-1303

Lonsdale DJ, Caron DA, Dennett MR, Schaffner R (2000) Predation by Oithona spp. on protozooplankton in the Ross Sea, Antarctica. Deep-Sea Res II 47:3273-3284

Marchant HJ, Murphy E (1994) Interactions at the base of the Antarctic food web. In: El-Sayed SZ (ed) Southern Ocean ecology, the BIOMASS perspective. Cambridge University Press, Cambridge, p 267-285

Morel A, Genitili B (2004) Radiation transport within oceanic (case 1) water. J Geophys Res 109, C06008, doi:10.1029/ 2003JC002259

Morel A, Huot Y, Gentili B, Werdell PJ, Hooker SB, Franz BA (2007) Examining the consistency of products derived from various ocean color sensors in open ocean (Case 1) waters in the perspective of a multi-sensor approach. Remote Sens Environ 111:69-88

Nagata T, Tamburini C, Arístegui J, Baltar F and others (2010) Emerging concepts on microbial processes in the bathypelagic ocean-ecology, biogeochemistry, and genomics. Deep-Sea Res II 57:1519-1536

Not F, Gausling R, Azam F, Heidelberg JF, Worden AZ (2007) Vertical distribution of picoeukaryotic diversity in the Sargasso Sea. Environ Microbiol 9:1233-1252

> Orsi AH, Wiederwohl CL (2009) A recount of Ross Sea waters. Deep-Sea Res II 56:778-795

Patterson DJ, Larson J (eds) (1991) The biology of free-living heterotrophic flagellates. Systematics Association Spec Vol No 45. Clarendon Press, Oxford 
Putt M, Stoecker DK (1989) An experimentally determined carbon: volume ratio for marine 'oligotrichous' ciliates from estuarine and coastal waters. Limnol Oceanogr 34: 1097-1103

Rivkin RB, Putland JN, Anderson MR, Deibel D (1999) Microzooplankton bacterivory and herbivory in the NE subarctic Pacific. Deep-Sea Res II 46:2579-2618

Rott E (1981) Some results from phytoplankton counting intercalibrations. Aquat Sci 43:34-62

Safi KA, Griffiths FB, Hall JA (2007) Microzooplankton composition, biomass and grazing rates along the WOCE SR3 line between Tasmania and Antarctica. Deep-Sea Res I 54:1025-1041

Scott FJ, Marchant HJ (eds) (2005) Antarctic marine protists. Australian Biological Resources Study, Canberra

Smith WO Jr, Anderson RF, Moore JK, Codispoti LA, Morrison JM (2000a) The US Southern Ocean joint global ocean flux study: an introduction to AESOPS. Deep-Sea Res II 47:3073-3094

Smith WO Jr, Marra J, Barber RT, Hiscock MR (2000b) The seasonal cycle of phytoplankton biomass and primary productivity in the Ross Sea, Antarctica. Deep-Sea Res II 47:3119-3140

Sohrin R, Imazawa M, Fukuda H, Suzuki Y (2010) Full-depth profiles of prokaryotes, heterotrophic nanoflagellates, and ciliates along a transect from the equatorial to the subarctic central Pacific Ocean. Deep-Sea Res II 57: $1537-1550$

Sokolov S, Rintoul SR (2002) Structure of Southern Ocean fronts at $140^{\circ} \mathrm{E}$. J Mar Syst 37:151-184

Sokolov S, Rintoul SR (2007) On the relationship between fronts of the Antarctic Circumpolar Current and surface chlorophyll concentrations in the Southern Ocean. J Geophys Res C 112, C07030, doi:10.1029/2006JC004072

Steinberg DK, Van Mooy BAS, Buesseler KO, Boyd PW, Kobari T, Karl DM (2008) Bacterial vs. zooplankton con-

Editorial responsibility: Urania Christaki, Wimereux, France trol of sinking particle flux in the ocean's twilight zone. Limnol Oceanogr 53:1327-1338

Strickland JDH, Parsons TR (1972) A practical handbook of seawater analysis, Bull 167, 2nd edn. Fish Res Board Can, Ottawa

Strom SL, Buskey EJ (1993) Feedings, growth, and behavior of the thecate heterotrophic dinoflagellate Oblea rotunda. Limnol Oceanogr 38:965-977

$>$ Tanaka T (2009) Structure and function of the mesopelagic microbial loop in the NW Mediterranean Sea. Aquat Microb Ecol 57:351-362

Tanaka T, Rassoulzadegan F (2002) Full-depth profile (0$2000 \mathrm{~m}$ ) of bacteria, heterotrophic nanoflagellates and ciliates in the NW Mediterranean Sea: vertical partitioning of microbial trophic structures. Deep-Sea Res II 49: 2093-2107

Throndsen J (1993) The planktonic marine flagellates. In: Thomas CR (ed) Marine phytoplankton: a guide to naked flagellates and coccolithophorids. Academic Press, London, p 7-145

Timmermans KR, Gerringa LJA, de Baar HJW, van der Wagt B and others (2001) Growth rates of large and small Southern Ocean diatoms in relation to availability of iron in natural seawater. Limnol Oceanogr 46:260-266

Tomas CR (1997). Identifying marine phytoplankton. Academic Press, San Diego, CA

> Vanucci S, Bruni V (1999) Small nanoplankton and bacteria in the Western Ross Sea during sea-ice retreat (spring 1994). Polar Biol 22:311-321

> Verity PG, Stoecker DK, Sieracki ME, Nelson JR (1993) Grazing, growth and mortality of microzooplankton during the 1989 North Atlantic spring bloom at $47^{\circ} \mathrm{N}, 18^{\circ} \mathrm{W}$. Deep-Sea Res I 40:1793-1814

Weisse T, Scheffel-Möser U (1990) Growth and grazing loss in single-celled Phaeocystis sp. (Prymnesiophyceae). Mar Biol 106:153-158

Submitted: July 26, 2011; Accepted: July 25, 2012

Proofs received from author(s): September 10, 2012 